\title{
First report of Calma glaucoides (Alder \& Hancock, 1854) (Nudibranchia, Calmidae) from Sweden
}

\author{
Leila Carmona $^{1}$ (1)
}

Received: 8 February 2016 / Revised: 26 August 2016/Accepted: 30 August 2016 / Published online: 12 September 2016

(C) The Author(s) 2016. This article is published with open access at Springerlink.com

\begin{abstract}
In the present contribution, the geographic range of Calma glaucoides Alder \& Hancock, 1854 is updated, since it was found for the first time in Sweden. This species was previously recorded from different localities in the northeastern Atlantic and western Mediterranean. A molecular approach was used to verify the identity of the specimens.
\end{abstract}

Keywords Mollusca $\cdot$ Aeolidida $\cdot$ Sweden $\cdot$ Biodiversity $\cdot$ New record

The nudibranch fauna in Sweden appears to be less studied than that in Norway. So far, the only monographic study of the Swedish Nudibranchia is that conducted by Malmberg and Lundin (2015), whereas Evertsen (2001) and Evertsen and Bakken (e.g. 2013) undertook intensive investigations on the nudibranch fauna from Norway. In the present paper, knowledge about the nudibranch fauna in Sweden is updated by reporting Calma glaucoides Alder \& Hancock, 1854 for the first time. Nine specimens, from 6 to $10 \mathrm{~mm}$ in length, were found along the western coast of Sweden (Fig. 1), in water $28 \mathrm{~m}$ deep on fine gravel substrate. The identity of the specimens was determined by molecular sequencing of tissue samples from freshly preserved specimens (not shown). Calma is a small genus that belongs to the monogeneric family Calmidae Iredale \& O'Donoghue, 1923, with only two species: Calma glaucoides and C. gobioophaga Calado \& Urgorri, 2002. The geographical distribution of this

Communicated by V. Urgorri

Leila Carmona

leila.carmona.barnosi@marine.gu.se

1 Department of Marine Sciences, University of Gothenburg, Box 460, 40530 Gothenburg, Sweden

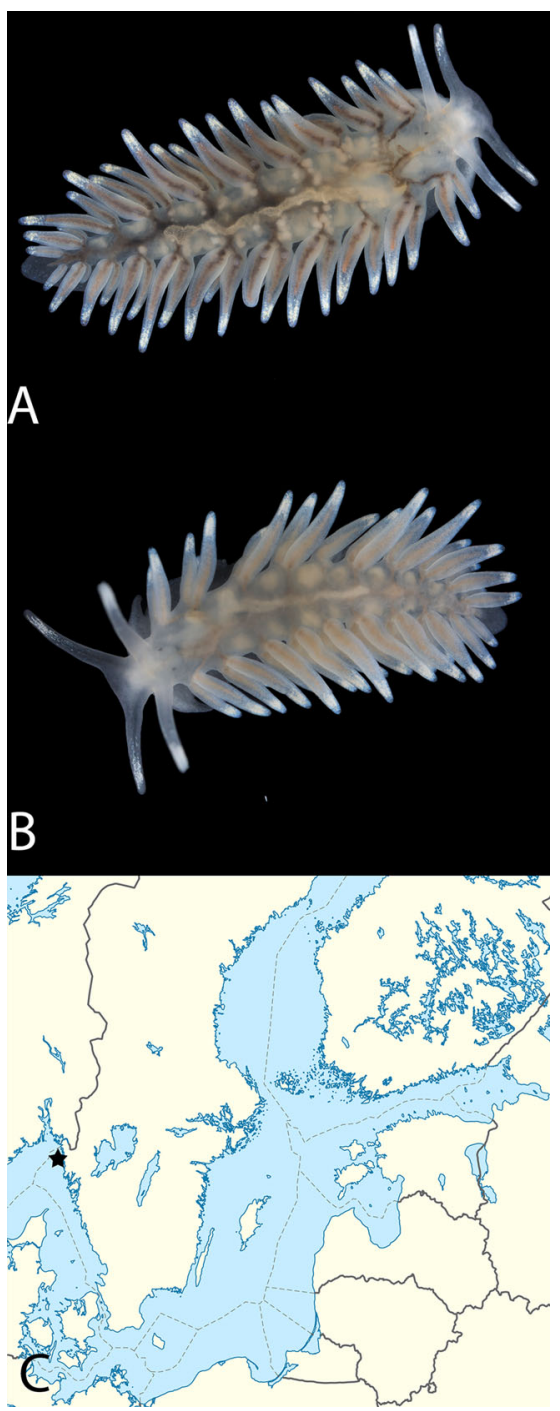

Fig. 1 a, b Photographs of the living animals of Calma glaucoides. a Specimen GNM Gastropoda 9029 and b specimen GNM Gastropoda 9030, photos by Fredrik Pleijel. c Collecting site of the specimens on the west coast of Sweden 
genus ranges from the northeastern Atlantic to the western Mediterranean (see Prkíc et al. 2014 for a map with all the records of Calma spp.). Within Scandinavia, thus far, Calmidae and C. glaucoides have been reported only three times, where it is only known from Norwegian waters (Evertsen and Bakken 2013). Evertsen and Bakken (2013) argued that the small number of records of $C$. glaucoides was a result of the difficulties in observing this species in situ. Moreover, during the last century, the Swedish nudibranch fauna has been largely ignored. Nevertheless, the compilation completed by Malmberg and Lundin (2015) updated the nudibranch fauna of Sweden with 89 species, including ten new records. All these new citations, including the one presented here, point out the necessity of a more complete revision of the Scandinavian fauna of Nudibranchia, in particular species from Swedish waters.

Acknowledgments Many thanks go to Mats Larsson and Fredrik Pleijel, who collected and provided specimens and images for this study. This work was supported by the Swedish Taxonomy Initiative (grant dha 2015-7 4.3).
Open Access This article is distributed under the terms of the Creative Commons Attribution 4.0 International License (http:// creativecommons.org/licenses/by/4.0/), which permits unrestricted use, distribution, and reproduction in any medium, provided you give appropriate credit to the original author(s) and the source, provide a link to the Creative Commons license, and indicate if changes were made.

\section{References}

Evertsen J (2001) Nakensneglfaunaen i Trondheimsfjorden og i Isfjorden på Svalbard. Systematikk og økologi. Hovedfagsoppgave i marin biologi til graden Candidatus scientiarum. Norges teknisk naturvitenskapelige universitet

Evertsen J, Bakken T (2013) Diversity of Norwegian sea slugs (Nudibranchia): new species to Norwegian coastal waters and new data on distribution of rare species. Fauna Norv 32:45-52

Malmberg K, Lundin K (2015) Svenska Nakensnäckor. Waterlog Productions, Halmstad

Prkíc J, Furfaro G, Mariottini P, Carmona L, Cervera JL, Modica MV, Oliverio M (2014) First record of Calma gobioophaga Calado and Urgorri, 2002 (Gastropoda: Nudibranchia) in the Mediterranean Sea. Mediterr Mar Sci 15:423-428 